\title{
ANALISIS DAYA SAING USAHA PEMBESARAN IKAN NILA PETANI PEMODAL KECIL DI KABUPATEN MUSI RAWAS
}

\section{Competitiveness Analysis of Tilapia Grower Business of Small Farmers in Musi Rawas Regency}

\author{
Verry Yarda Ningsih, Putri Suci Asriani, Sriyoto \\ Prodi Magister Agribisnis Fakultas Pertanian Universitas Bengkulu \\ Verryyarda.ningsih@yahoo.co.id
}

\begin{abstract}
This research was done to investigate whether tilapia growers has business competitiveness both in competitive and comparative. This study aimed to analyze the competitive advantage, comparative advantage, the impact of government policies on output and input. Effect of output and input changing based on a sensitivity analysis on the competitiveness of tilapia fish rearing business, the level of tilapia grower business competitiveness between small farmers in Musi Rawas regency. The respondent was determined by purposive method deliberately carried out in accordance with the criteria set by the researcher. The respondents was conducted by using proportionate stratified random sampling. This study used the primary data and secondary data. The result of Pam Method shows that a small farmers of tilapia enlargement at musi rawas regency has competitive advantage with $P C R<1$ by 0,55. It also has comparativeadvantage with $D R C R<0,37$. The goverment policies toward tradadable input produkction were in the form of subsidies. Based of sensitivity analysis the enlargemen of tilapia will be lost if tilapia production decrease $10 \%$, the price of tilapia it self decrease 5,5\% and if the feed price increase $7 \%$.
\end{abstract}

Keywords: small farmers, competitive, comparative, sensitivity

\section{PENDAHULUAN}

Indonesia merupakan negara yang memiliki tingkat produksi ikan yang cukup tinggi setiap tahunnya, disampaikan oleh Menteri Perikanan dan Kelautan bahwa Indonesia memberi pasokan ikan cukup banyak untuk negara-negara luar negeri. Indonesia menduduki peringkat ke 2 dalam mengekspor ikan di dunia setelah negara china.

Total Volume ekspor untuk hasil perikanan Indonesia mengalamai peningkatan sebesar 6,02\% pada tahun 2012, dari 1.159 juta ton pada tahun 2011 menjadi sebesar 1.229 juta ton, sedangkan berdasarkan nilai dibandingkan tahun 2011, total nilai ekspor ditandai dengan kenaikan nilai ekspor hasil perikanan tahun 2012 sebesar 9,44\% dari US\$ 3,52 milyar ditahun 2011 menjadi 3,85 Milyar ditahun 2012 (BPS, 2012) 
ISSN: 1412-8837

Berdasarkan Publikasi Direktorat Jenderal Perikanan Budidaya tahun 2013 menyatakan bahwa produksi perikanan di Indonesia memiliki berbagai jenis budidaya yaitu :budidaya laut, tambak, kolam, kerambah, jaring apung dan sawah. Berikut dapat dijelaskan pada tabel 1.

Tabel 1. Produksi Perikanan Budidaya di Indonesia tahun 2009 - 2012

\begin{tabular}{|c|c|c|c|c|}
\hline Komoditas & $\begin{array}{l}2009 \\
\text { (ton) }\end{array}$ & $\begin{array}{l}2010 \\
\text { (ton) }\end{array}$ & $\begin{array}{l}2011 \\
\text { (ton) }\end{array}$ & $\begin{array}{l}2012 \\
\text { (ton) }\end{array}$ \\
\hline Kerapu & 8.791 & 10.398 & 11.950 & 14.400 \\
\hline Kakap & 6.400 & 5.738 & 6.198 & 7.504 \\
\hline Bandeng & 328.288 & 421.757 & 518.939 & 667.116 \\
\hline Patin & 109.685 & 147.888 & 347.000 & 972.778 \\
\hline Nila & 323.389 & 464.191 & 695.063 & 1.604 .810 \\
\hline Ikan Mas & 249.279 & 282.695 & 374.366 & 340.863 \\
\hline Lele & 144.755 & 242.811 & 441.217 & 758.455 \\
\hline Gurame & 46.254 & 64.252 & 84.681 & 86.773 \\
\hline
\end{tabular}

Sumber: Ditjen Perikanan Budidaya (2013)

Perkembangan Produksi Perikanan dari tahun 2009 sampai dengan tahun 2012 mengalami perkembangan produksi yang cukup tinggi yakni mencapai 30,08\%, kecuali untuk komoditas Ikan Mas yang mengalami penurunan di tahun 2012 sebesar 33.503 ton atau 8,9\%. Sedangkan komoditas Ikan Nila dan Ikan lele mengalami peningkatan produksi sebesar 909.747 ton. Sumatera Selatan merupakan salah satu provinsi terbesar penghasil produk perikanan dari budidaya yaitu sebesar 435.001 ton (BPS, 2013). Berikut pada Tabel 2 dijelaskan Sepuluh (10) peringkat provinsi terbesar penghasil perikanan budidaya di Indonesia.

Tabel 2. Sepuluh Provinsi Terbesar Penghasil Perikanan Budidaya

\begin{tabular}{lcc}
\hline Provinsi & Jumlah Produksi (ton) & Persentase (\%) \\
\hline Sulawesi Selatan & 2.592 .121 & 19,49 \\
Nusa Tenggara Timur & 1.849 .455 & 13,90 \\
Sulawesi Tenggara & 1.010 .925 & 7,60 \\
Jawa Timur & 995.963 & 7,49 \\
Jawa Barat & 991.045 & 7,45 \\
Nusa Tenggara Barat & 719.358 & 5,41 \\
Maluku & 592.001 & 4,45 \\
Sumatera Selatan & 435.001 & 3,27 \\
Jawa Tengah & 389.215 & 2,93 \\
Sumatera Barat & 206.871 & 1,56 \\
Provinsi lain & 3.518 .951 & 26,46 \\
\hline Total & $\mathbf{1 3 . 3 0 0 . 9 0 6}$ & $\mathbf{1 0 0}$ \\
\hline
\end{tabular}

Sumber: Badan Pusat Statistik tahun 2013

280 | Verry Yarda N., Putri Suci A., dan Sriyoto, Analisis Daya Saing... 
Kabupaten Musi Rawas merupakan salah satu kawasan minapolitan di Provinsi Sumatera Selatan, kawasan minapolitan Kabupaten Musi Rawas terdiri dari 3 wilayah yakni Kecamatan Tugumulyo, Kecamatan Purwodadi dan Kecamatan Muara Beliti. Penetapan lokasi minapolitan berdasarkan “Keputusan Bupati Musi Rawas Nomor 381/KPTS/DISNAKKAN/2010 dan tentang Pembentukan Kelompok Kerja (Pokja) berdasarkan Keputusan Bupati Musi Rawas Nomor 65/KPTS/DISNAKKAN/2011". Pada Tabel 3. dapat dilihat produksi perikanan budidaya untuk komoditas unggulan Kabupaten Musi Rawas.

Tabel 3. Produksi Perikanan Budidaya Kabupaten Musi Rawas tahun 20102014

\begin{tabular}{rlrrrrr}
\hline \multirow{2}{*}{ No } & \multirow{2}{*}{ Komoditas } & \multicolumn{5}{c}{ Realisasi Produksi (ton) } \\
\cline { 3 - 7 } & & \multicolumn{1}{c}{$\mathbf{2 0 1 0}$} & \multicolumn{1}{c}{$\mathbf{2 0 1 1}$} & \multicolumn{1}{c}{$\mathbf{2 0 1 2}$} & \multicolumn{1}{c}{$\mathbf{2 0 1 3}$} & \multicolumn{1}{c}{$\mathbf{2 0 1 4}$} \\
\hline 1 & Nila & $10.879,73$ & $17.629,05$ & $10.137,52$ & $32.857,68$ & $39.184,42$ \\
2 & Mas & $5.292,70$ & $10.629,34$ & $6.492,97$ & $5.169,20$ & $7.123,80$ \\
3 & Lele & $1.991,87$ & $11.973,58$ & $10.946,37$ & $12.109,66$ & $23,159.47$ \\
4 & Patin & 35,17 & 85,16 & 32,19 & 257,48 & 222,43 \\
5 & Gurami & 69,46 & 168,17 & 86,32 & 94,87 & 53,29 \\
6 & Lainnya & 76,88 & 186,12 & 73,97 & 85,44 & 53,71 \\
\hline
\end{tabular}

Sumber: Dinas Peternakan dan Perikanan Kabupaten Musi Rawas (2015)

Ikan Nila pada kawasan Minapolitan di Kabupaten Musi Rawas mendapatkan posisi yang baik, hal ini ditunjukkan dari data produksi tertinggi sejak tahun 2010 -2014, dan ikan nila menunjukkan trend pertumbuhan yang positif. Akan tetapi untuk petani pemodal kecil mengalami kesulitan dalam perkembangan usaha, teknik budidaya yang dilakukan dalam pembesaran ini pun bervariasi sesuai dengan ketersediaan modal. Produksi ikan nila Kawasan Minapolitan dipasarkan di Kabupaten Musi Rawas dan sekitarnya selain itu juga ikan nila ini dipasarkan di luar Kabupaten Musi Rawas yaitu daerah Bengkulu, Jambi, Pekan baru dan Palembang. Oleh karena itu penelitian ini penting untuk dilakukan guna melihat daya saing usaha pembesaran ikan nila di Kabupaten Musi Rawas.

Berdasarkan paparan latar belakrang diatas, maka rumusan masalah yang disusun dalam penelitian ini adalah :

1. Bagaimana keunggulan kompetitif usaha pembesaran ikan nila petani pemodal kecil di Kabupaten Musi Rawas.

2. Bagaimana keunggulan komparatif usaha pembesaran ikan nila petani pemodal kecil di Kabupaten Musi Rawas

3. Bagaimana dampak kebijakan pemerintah terhadap output dan input didalam usaha pembesaran ikan nila petani pemodal kecil besar di Kabupaten Musi Rawas

4. Bagaimana Pengaruh Perubahan output dan input berdasarkan analisis sensitivitas terhadap daya saing usaha pembesaran ikan nila petani pemodal kecil di Kabupaten Musi Rawas. 
5. Bagaimana tingkat daya saing usaha pembesaran ikan nila petani pemodal kecil di Kabupaten Musi Rawas.

\section{METODE PENELITIAN}

Penelitian ini merupakan penelitian survey yang digunakan untuk mendapatkan atau mengumpulkan informasi langsung dari sekelompok individu atau sampel dan sampel ini merupakan bagian dari populasi yang menjadi objek penelitian. Penentuan lokasi penelitian dilakukan dengan sengaja di Kabupaten Musi rawas dengan pertimbangan bahwa Kabupaten Musi Rawas merupakan salah satu kawasan minapolitan yang ada di Sumatera Selatan. Data yang digunakan dalam penelitian ini adalah data di tahun 2014. Populasi dalam penelitian ini adalah pembudidaya ikan nila dan pengusaha ikan nila yang berada di kawasan minapolitan yang terdiri dari 3 Kecamatan Yakni Kecamatan Tugumulyo memiliki 17 desa, Kecamatan Purwodadi memiliki 11 Desa dan Kecamatan Muara Beliti memiliki 11 desa. Metode penentuan responden adalah dengan metode Purpossive yaitu sengaja dilakukan sesuai dengan kriteria yang telah ditetapkan oleh peneliti yakn:

Kriteria responden untuk pembudidaya pemodal kecil adalah sebagai berikut:

- Petani pemilik kolam ikan nila air tenang (kolam sawah)

- Usaha ikan nila dengan luas lahan kolam rata-rata $500 \mathrm{~m}^{2}-2.500 \mathrm{~m}^{2}$ dengan kedalaman $0,5 \mathrm{~m}-1,5 \mathrm{~m}$

- Kapasitas ikan per kolam 5.000 - 25.000 bibit ikan ( $1,5 \mathrm{~kg}-9 \mathrm{~kg})$

- Ukuran ikan yang dimasukkan kedalam kolam 3.000 ekor / kg

- Merupakan anggota kelompok yang mendapatkan bantuan dari pemerintah

- Lama Pembesaran ikan 4 - 5 bulan

- Produksi ikan 3 - 4 ekor / kg.

Populasi dalam penelitian ini adalah pembudidaya ikan nila dan pengusaha ikan nila yang berada di kawasan minapolitan Kabupaten Musi Rawas yang terdiri dari 3 Kecamatan yakni Kecamatan Tugumulyo yang memiliki 17 desa, Kecamatan Purwodadi dengan 11 desa, dan Kecamatan Muara Beliti dengan 11 desa. Cara menentukan jumlah responden yakni dengan cara purpossive dengan pertimbangan bahwa populasi petani ikan sudah homogen dan sesuai dengan kebutuhan penelitian, menurut Riduwan dan Sunarto (2009) paling sedikit $10 \%$ dalam menentukan jumlah responden. Pada penelitian ini digunakan sebanyak $30 \%$ dari jumlah populasi yakni untuk petani pemodal kecil $30 \% \times 50$ orang $=15$ orang.

Metode pengambilan responden dilakukan dengan metode Proportonate Stratified Random Sampling menurut Sugiyono (2008), Pengambilan responden untuk petani pemodal kecil pada kawasan minapolitan Kabupaten Musi Rawas yakni:

Kecamatan Tugumulyo $=20 / 50 \times 15$ orang $=6$ orang

282 | Verry Yarda N., Putri Suci A., dan Sriyoto, Analisis Daya Saing... 
Kecamatan Purwodadi $=20 / 50 \times 15$ orang $=6$ orang

Kecamatan Muara Beliti $=10 / 50 \times 15$ orang $=3$ orang

Data yang digunakan pada penelitian ini adalah data primer dan data sekunder.

1. Data primer dalam penelitian ini adalah wawancara kepada sejumlah petani, pengusaha dan informan yang terlibat langsung dalam kegiatan usahatani ikan nila dan dengan menggunkan kuisioner yang terstruktur.

2. Data sekunder dikumpulkan dari berbagai literature, dokumen hasil penelitian pada instansi perikanan, BPS, dan stakeholder lainnya yang berupa hasil-hasil penelitian sejenis baik komoditas ataupun alat analisis, data luas lahan kolam ikan serta produksi ikan, dan profil wilayah kabupaten Musi Rawas.

Penelitian ini dianalisis menggunakan Analisis PAM (Policy Anlayisis Matrix) yang telah dikembangkan oleh Monke dan Person sejak tahun 1987. Analisis ini dapat digunakan pada sistem komoditas dengan berbagai wilayah, tipe usahatani, dan teknologi. Selain itu analisis PAM juga dapat digunakan untuk mengetahui apakah suatu kebijakan dapat memperbaiki daya saing terhadap pengusahaan suatu komoditi yang dihasilkan dari penciptaan efisiensi usaha dan pertumbuhan pendapatan.

\section{Analisis Daya saing}

Analisis Keuntungan

Private Profitability (PP), yaitu D = A- (B+C). Keuntungan privat merupakan indikator daya saing (competitiveness). Apabila $\mathrm{D}>0$, berarti sistem komoditas tersebut memperoleh profit diatas normal. Hal ini mempunyai implikasi bahwa komoditas tersebut mampu ekspansi. Sebaliknya, bila Nilai D $\leq 0$, berarti sistem komoditas tersebut memperoleh profit dibawah normal dan belum mampu ekspansi.

Sosial Profitability (SP), yaitu $\mathrm{H}=\mathrm{E}-(\mathrm{F}+\mathrm{G})$. Keuntungan sosial merupakan indikator keuntungan komparatif (comparative advantage) atau efisiensi dari sistem komoditas pada kondisi tidak ada divergensi dan penerapan kebijakan yang efisien, apabila $\mathrm{H}>0$. Sebaliknya, bila $\mathrm{H} \leq 0$, berarti sistem komoditas tidak mampu bersaing tanpa bantuan atau intervensi pemerintah.

\section{Keunggulan Kompetitif PCR dan Keunggulan Komparatif DR Private Cost Rasio $(\mathrm{PCR})=\mathrm{C} /(\mathrm{A}-\mathrm{B})$}

Apabila nilai PCR $<1$ dan nilainya makin kecil, berarti sistem produksi usahatani pembesaran ikan nila semakin kompetitif dan mampu membiayai faktor domestiknya pada harga privat dan kemampuannya tersebut akan meningkat. Sebaliknya bila, $P C R \geq 1$, sistem komoditas yang diteliti tidak memiliki keunggulan kompetitif. 


\section{Domestic Resources Cost Ratio (DRCR) $=G /(E-F)$}

Jika DRCR < 1, maka sistem komoditas mempunyai keunggulan komparatif. Sebaliknya jika DRCR $\geq 1$ sistem komoditas tidak memiliki keunggulan komparatif.

\section{Dampak Kebijakan Pemerintah}

Kebijakan Terhadap Output

\section{Output Transfer (OT) : I = A - E}

Jika nilai OT $>0$ menunjukkan adanya transfer dari masyarakat (konsumen) kepada produsen, sebaliknya bila OT $\leq 0$, menunjukkan tidak ada transfer dari masyarakat (konsumen) kepada produsen.

\section{Nominal Protection Coefficient on Output $(\mathrm{NPCO})=\mathrm{A} / \mathrm{E}$}

Jika nilai NPCO > 1. Semakin besar nilai NPCO, berarti semakin besar tingkat proteksi pemerintah terhadap output, sebaliknya bila NPCO $\leq 1$, kebijakan bersifat disinsentif.

\section{Kebijakan Terhadap Input}

Input Transfer (IT) : $J=B-F$

Jika nilai IT $>0$, menunjukkan adanya transfer dari petani pembesaran ikanbnila ke produsen kepada input tradable, sebaliknya bila IT $\leq 0$, menunjukkan tidak adanya transfer dari petani ke produsen input tradable Nominal Protection Coefficien on Tradable Input $(N P C I)=B / F$. NPCI merupakan indicator yang menunjukkan tingkat proteksi pemerintah terhadap harga input domestic.

Jika nilai NPCI $<1$, berarti kebijakan bersifat protektif terhadap input, ada kebijakan subsidi terhadap input tradable, sebaliknya bila NPCI $\geq 1$, berarti tidak ada kebijakan protektif terhadap input/ tidak ada kebijakan subsidi terhadap input tradable Transfer Factor

\section{Transfer Factor (TF): $K=C-G$}

Transfer faktor merupakan nilai yang menunjukkan perbedaan harga privat dengan harga sosialnya yang diterima produsen untuk pembayaran faktor-faktor produksi yang tidak diperdagangkan ( non tradable). Nilai TF $>0$ berarti bahwa ada transfer dari petani kepada produsen input non tradable atau pemerintah, sebaliknya bila TF $\leq 0$ berarti tidak ada transfer dari petani kepada produsen input non tradable

\section{Kebijakan Terhadap Input-Output}

Effective Protection Coefficient $(\mathrm{EPC})=(\mathrm{A}-\mathrm{B}) /(\mathrm{E}-\mathrm{F})$

EPC merupakan indikator yang menunjukkan tingkat proteksi simultan terhadap output dan input tradable. Kebijakan masih bersifat protektif, jika nilai EPC $>1$. Semakin besar nilai EPC, berarti semakin tinggi tingkat proteksi pemerintah terhadap komoditas domestik. 
Net Transfer (NT): L = D - H

Transfer bersih merupakan selisih antara keuntungan bersih yang benarbenar diterima produsen dengan keuntungan bersih sosialnya. Nilai NT $>0$, menunjukkan tambahan surplus produsen yang disebabkan oleh kebijakan pemerintah yang diterapkan pada input dan output, demikian juga sebaliknya.

\section{Profitability Coefficient $(\mathrm{PC})=\mathrm{D} / \mathrm{H}$}

Koefisien keuntungan adalah perbandingan antara keuntungan bersih yang benar-benar diterima produsen dengan keuntungan bersih sosialnya. Jika PC $>0$, berarti secara keseluruhan kebijakan pemerintah memberikan insentif kepada konsumen, demikian juga sebaliknya.

\section{Subsidy Ratio to Producer (SRP) = L / E}

Rasio subsidi produsen (SRP) merupakan indikator yang menunjukkan proporsi penerimaan pada harga sosial yang diperlukan apabila subsidi atau pajak digunakan sebagai pengganti kebijakan. Nilai SRP yang negatif menunjukkan bahwa kebijakan pemerintah yang berlaku selama ini menyebabkan produsen mengeluarkan biaya produksi lebih besar dari biaya imbangan (opportunity cost) untuk berproduksi dan sebaliknya jika nilai SRP positif.

\section{Analisis Sensitivitas}

Analisis sensitivitas dilakukan untuk melihat bagaimana hasil analisis suatu aktivitas ekonomi pada usaha pembesaran ikan nila bila terjadi perubahan terhadap input dan output pada usaha pembesaran ikan nila di Kabupaten Musi Rawas Perubahan yang dimasukkan pada penelitian ini adalah perubahan harga output dan input yakni:

1. Peningkatan harga input

2. Penurunan harga output (produksi)

3. Penurunan jumlah produksi

Besarnya penambahan akan ditentukan dengan metode trial dan eror (coba-coba) berdasarkan kecendrungan naik turunnya harga yang selama ini terjadi.

\section{HASIL DAN PEMBAHASAN}

\section{Karakteristik Petani Usaha Pembesaran Ikan Nila}

Pada usahatani budidaya ikan nila terdiri dari petani pemodal kecil. Berikut adalah karakteristik responden pada penelitian tentang daya saing usahatani budidaya ikan nila pemodal kecil yang amati meliputi umur, tingkat pedidikan, pegalaman berusaha tani, pendidikan formal, pendidikan non formal, pekerjaan sampingan, jumlah anggota keluarga, luas lahan usaha tani yang dapat dilihat pada Tabel 4 . 
ISSN: $1412-8837$

Tabel 4. Karakteristik Petani

\begin{tabular}{|c|c|c|c|c|}
\hline \multirow{2}{*}{ No } & \multirow{2}{*}{ Uraian Karakteristik } & \multicolumn{3}{|c|}{ Pemodal Kecil } \\
\hline & & Frekuensi & $\%$ & Rata-rata \\
\hline \multirow[t]{5}{*}{1} & Umur (Tahun) & & & \\
\hline & a. Muda (29-35) & 4 & 26,67 & \\
\hline & b. Sedang (36-42) & 5 & 33,33 & 40,73 \\
\hline & c. Tua $(43-50)$ & 6 & 40 & \\
\hline & Total & 15 & 100 & \\
\hline \multirow[t]{8}{*}{2} & Pendidikan & & & \\
\hline & a. $\mathrm{SD}$ & 3 & 20 & \\
\hline & b. SMP & 5 & 33,33 & \\
\hline & c. SMA & 5 & 33,33 & \\
\hline & d. D1 & 0 & 0 & \\
\hline & e. D2 & 1 & 6,667 & \\
\hline & f. S1 & 1 & 6,667 & \\
\hline & Total & 15 & 100 & \\
\hline \multirow[t]{5}{*}{3} & Jumlah Tanggungan Keluarga (Orang) & & & \\
\hline & a. Sedikit (1) & 1 & 6,667 & \\
\hline & b Sedang (2) & 6 & 40 & 2,47 \\
\hline & c. Banyak (3) & 8 & 53,33 & \\
\hline & Total & 15 & 100 & \\
\hline \multirow[t]{5}{*}{4} & Pengalaman Usahatani (Tahun) & & & \\
\hline & a. Baru (3-6) & 6 & 40 & \\
\hline & b. Sedang $(7-10)$ & 6 & 40 & 7,93 \\
\hline & c. Lama (11-15) & 3 & 20 & \\
\hline & Total & 15 & 100 & \\
\hline \multirow[t]{5}{*}{5} & Luas Lahan (Hektar) & & & \\
\hline & a. Sempit $(0,25-0,50)$ & 11 & 73,33 & \\
\hline & b. Sedang $(0,51-0,75)$ & 2 & 13,33 & 0,19 \\
\hline & c. Luas $(0,76-1)$ & 2 & 13,33 & \\
\hline & Total & 15 & 100 & \\
\hline \multirow[t]{5}{*}{6} & Jarak Lahan (M) & & & \\
\hline & a. Dekat (50-533) & 13 & 86,67 & \\
\hline & b. Sedang (533-1016) & 1 & 6,667 & 368,33 \\
\hline & c. Jauh $(1016-1500)$ & 1 & 6,667 & \\
\hline & Total & 15 & 100 & \\
\hline \multirow[t]{5}{*}{7} & Pekerjaan & & & \\
\hline & a. Petani & 13 & 86,67 & \\
\hline & b. Widyawisata & 1 & 6,667 & Petani \\
\hline & c. Guru & 1 & 6,667 & \\
\hline & Total & 15 & 100 & \\
\hline
\end{tabular}

Sumber: Data Diolah, 2015

286 | Verry Yarda N., Putri Suci A., dan Sriyoto, Analisis Daya Saing... 


\section{Analisis Daya Saing Usaha Pembesaran Ikan Nila}

Pendekatan yang digunakan untuk mengukur daya saing suatu komoditas dapat dilihat dari keuntungan kompetitif dan komparatif. Salah satu alat analisis yang dapat digunakan untuk mengetahui daya saing suatu komoditi (keunggulan kompetitif dan keunggulan komparatif) adalah matriks analisis kebijakan atau PAM (Policy Analysis Matriks) yang disusun berdasarkan data penerimaan, biaya produksi dan biaya lainnya yang dihitung berdasarkan harga finansial (privat) dan harga ekonomi (bayangan atau sosial). Masing-masing biaya produksi pada harga finansial dan ekonomi dibagi menjadi komponen tradable (asing) dan non tradable (domestik).

\section{Analisis Keuntungan}

Analisis Keunggulan Kompetitif Usaha Pembesaran Ikan Nila

Tabel 5. Analisis Keunggulan Kompetitif Matriks PAM

\begin{tabular}{cccl}
\hline Uraian & Simbol & Hasil & \multicolumn{1}{c}{ Kesimpulan } \\
\hline Privat Profitability & PP & 5.531 .734 & $\begin{array}{l}\text { D }>0, \text { Komoditas ikan nila } \\
\text { mampu ekspansi karena }\end{array}$ \\
& & & $\begin{array}{l}\text { memiliki keuntungan yang } \\
\text { diterima langsung petani }\end{array}$ \\
Privat Cost Ratio & PCR & \multirow{2}{*}{0.55} & $\begin{array}{l}\text { PCR }<1, \text { Komoditas yang } \\
\text { diteliti memiliki keunggulan } \\
\end{array}$ \\
& & yang kompetitif.
\end{tabular}

Sumber: Data diolah, 2015

\section{Analisis Keunggulan Komparatif Usaha Pembesaran Ikan Nila}

Keunggulan komparatif suatu komoditas ditentukan oleh nilai-nilai keuntungan sosial (SP/Social Provitability) dan nilai ratio sumber daya domestik (DRCR/Domestic Resource Cost Ratio).

Tabel 6. Analisis Keunggulan Komparatif Matriks PAM

\begin{tabular}{|c|c|c|c|}
\hline Uraian & Simbol & Hasil & Kesimpulan \\
\hline Privat Profitability & SP & 11.378 .507 & $\begin{array}{l}\text { SP }>0 \text {, ada efisiensi dari } \\
\text { sistem komoditas pada } \\
\text { kondisi tidak divergensi dan } \\
\text { penerapan kebijakan efisiens. }\end{array}$ \\
\hline Privat Cost Ratio & DRCR & 0.37 & $\begin{array}{l}\text { DRCR }<1 \text {, Komoditas yang } \\
\text { diteliti memiliki keunggulan } \\
\text { yang komparatif. }\end{array}$ \\
\hline
\end{tabular}

Sumber: Data diolah, 2015

Hasil analisis dengan metode PAM menunjukkan bahwa nilai keuntungan sosial/SP untuk usaha pembesaran ikan nila pada pemodal kecil di Kabupaten Musi Rawas adalah Rp. 11.378.507 ini menunjukkan bahwa usaha pembesaran ikan nila di Kabupaten Musi Rawas layak diusahakan dan memiliki keuntungan komparatif. Keuntungan sosial adalah keuntungan yang 
diperoleh jika terjadi pasar persaingan sempurna, dimana tidak ada campur tangan pemerintah dan kegagalan pasar.

Nilai ratio sumber daya domestik/DRCR usaha pembesaran ikan nila pada pemodal kecil di Kabupaten Musi Rawas berdasarkan hasil analisis adalah 0,37, nilai tersebut menunjukkan bahwa untuk mendapatan 1 unit nilai tambah diperlukan biaya domestik sebesar 0.11 unit pada usaha pembesaran ikan nila pada pemodal kecil di Kabupaten Musi Rawas.

\section{Dampak Kebijakan Pemerintah}

Setiap negara berkembang memiliki kebijakan pemerintah pada sektor pertanian sehingga dapat menetukan keberhasilan pengembangan dan usaha dalam rangka menambah devisa negara. Suatu kebijakan pemerintah dalam suatu aktivitas ekonomi dapat meberikan dampak positif dan negatif terhadap pelaku ekonomi.

\section{Dampak Kebijakan Pemerintah Terhadap Output}

Kebijakan pemerintah berupa subsidi dan pajak pada suatu komoditas agribisnis dapat berpengaruh positif dan negatif bagi para pelakunya. Indikator dampak kebijakan pemerintah terhadap output dapt dilihat dengan menggunkan nilai OT (Output Transfer) dan NPCO (Nominal Protection Coefficient On Output).

\section{Tabel 7. Dampak Kebijakan Pemerintah Terhadap Output}

\begin{tabular}{|c|c|c|c|}
\hline Uraian & Simbol & Hasil & Kesimpulan \\
\hline Output Transfer & OT & 5.910 .481 .48 & $\begin{array}{l}\text { Tidak adanya transfer dari } \\
\text { masyarakat (Konsumen) ke } \\
\text { Produsen }\end{array}$ \\
\hline $\begin{array}{l}\text { Nominal Protection } \\
\text { Coefficient Output }\end{array}$ & $\mathrm{NPCO}$ & 0.91 & Kebijakan bersifat disinsetif \\
\hline
\end{tabular}

Sumber: Data diolah, 2015

Hasil analisis metode PAM diketahuibahwa nilai OT pada usaha pembesaran ikan nila adalah negatif artinya harga privat pada pemodal besar dan pemodal kecil lebih rendah daripada harga sosialnya. Kondisi ini menunjukkan bahwa adanya intervensi pemerintah pada output terhadap usaha pembesaran ikan nila ini lebih menguntungkan konsumen, karena konsumen membeli harga yang lebih rendah dari harga sebenarnya. Dengan kata lain, terjadi pengalihan surplus dari produsen ke konsumen.

\section{Dampak kebijakan pemerintah terhadap input}

Kebijakan pemerintah tidak saja berlaku untuk output namun berlaku pula untuk harga input. Adapun indikator-indikator yang digunakan untuk melihat intervensi pemerintah terhadap input produksi adalah nilai transfer (IT), Transfer Faktor (TF), dan koefisien proteksi nominal pada input/Nominal Protection Coefisien on Tradabel Input. 
Tabel 8. Dampak kebijakan Pemerintah terhadap Input

\begin{tabular}{cccl}
\hline Uraian & Simbol & Hasil & \multicolumn{1}{c}{ Kesimpulan } \\
\hline Input Transfer & IT & $45,670,801.48$ & $\begin{array}{l}\text { Menunjukkan tidak adanya } \\
\text { transfer dari petani ke } \\
\text { produsen input tradable }\end{array}$ \\
Transfer Factor & TF & $12,526.60$ & $\begin{array}{l}\text { Adanya transfer dari petani } \\
\text { produsen ke produsen input } \\
\text { tradable }\end{array}$ \\
\hline
\end{tabular}

Sumber: Data diolah, 2015

Hasil analisis dengan menggunakan metode PAM diketahui bahwa nilai IT adalah negatif. Nilai IT menggambarkan kebijakan subsidi atau pajak yang terjadi pada input tradable. Nilai negatif untuk usaha pembesaran ikan nila menunjukkan bahwa terdapat kebijakan subsidi terhadap input produksi tradable dalam usaha pembesaran ikan nila. Hal tersebut menguntungkan bagi petani budidaya ikan nila karena terdapat kebijakan pemerintah berupa subsidi atas input tradable yang menyebabkan harga yang dibayarkan petani terhadap input tersebut lebih rendah dari harga sebenarnya.

\section{Analisis Sensitifitas Terhadap Daya Saing Usaha Pembesaran Ikan Nila}

Perubahan-perubahan yang terjadi dalam usaha pembesaran ikan nila akan berpengaruh terhadap daya saing usaha pembesaran ikan nila di Kabupaten Musi Rawas. Keterbatasan Matriks Analisis Kebijakan PAM yakni analisis yang digunakan bersifat statis (hanya berlaku pada musim).

\section{Analisis Sensitifitas jika terjadi penurunan produksi ikan nila}

Simulasi pertama yang dilakukan adalah penurunan jumlah produksi ikan nila, ceteris paribus, Penurunan jumlah ikan nila sebesar 10\%. Penurunan jumlah output tersebut akan berpengaruh pada daya saing yang dianalisis. Hasil analisis sensitifitas menunjukkan bahwa setelah terjadi penurunan output hingga 10\% menyebabkan daya saing ikan nila pada petani pemodal kecil di Kabupaten Musi Rawas semakin melemah. Hal tersebut dapat dilihat dari nilai PCR yang melewati angka 1 yang berarti bahwa usaha pembesaran ikan nila pada petani pemodal kecil di kabupaten Musi Rawas tidak memiliki keunggulan kompetitif. Penurunan output sebesar $10 \%$ juga menyebabkan nilai DRCR pada petani pemodal kecil melemah, akan tetapi dengan penurunan output sebesar $10 \%$ tersebut usaha pembesaran ikan nila masih memiliki keunggulan komparatif.

\section{Analisis Sensitifitas jika terjadi penurunan harga Ikan Nila}

Penurunan harga output akan berdampak terhadap daya saing dari usaha pembesaran ikan nila di Kabupaten Musi Rawas yang akan dianalisis. Setelah terjadi perubahan penurunan harga ouput 5,5\% menyebabkan keuntungan privat nilai PP menjadi kurang dari 0 pada petani pemodal kecil. Keuntungan sosial atau nilai SP menjadi berkurang atau melemah yakni 
sebesar Rp. 6.464.076. Nilai PCR untuk petani pemodal kecil menjadi lebih dari 1 yang berarti bahwa ikan nila di kabupaten musi rawas tidak memiliki keunggulan kompetitif. nilai DRCR untuk petani pemodal kecil masih berada di bawah angka 1 yag menunjukkan bahwa walaupun terjadi penurunan harga output sebesar 5,5\% usaha pembesaran ikan nila dikabupaten Musi Rawas masih memiliki keunggulan Komparatif.

\section{Analisis Sensitifitas jika terjadi peningkatan harga pakan}

Pakan merupakan salah satu input produksi yang sangat penting dan bernilai besar dari usaha pembesaran ikan nila karena besar kecilnya tingkat produksi ikan tergantung dari pakan yang digunakan dalam usaha pembesaran ikan nila. Pada penelitian ini peneliti mensimulasikan harga pakan meningkat menjadi $7 \%$ dari harga yang berlaku pada saat penelitian, dengan peningkatan harga pakan menjadi 7\% maka usaha pembesaran ikan nila yang dijalankan oleh petani pemodal kecil akan mengalami kerugian karena nilai PP dibawah 0. Nilai PCR untuk petani pemodal kecil menjadi lebih dari 1 yang berarti bahwa dengan peningkatan harga pakan ikan sebesar 7\% membuat usaha tersebut menjadi tidak kompetitif, Nilai DRCR untuk petani pemodal kecil 1 yang menunjukkan bahwa walaupun terjadi kenaikan harga pakan ikan sebesar 7\% tetapi usaha pembesaran ikan nila di Kabupaten Musi Rawas masih memiliki keunggulan komparatif.

\section{SIMPULAN DAN SARAN}

\section{Simpulan}

Berdasarkan hasil penelitian yang dilakukan maka dapat disimpulkan :

1. Usaha pembesaran ikan nila di Kabupaten Musi Rawas pada pemodal kecil memiliki keunggulan kompetitif yang ditandai dengan nilai PCR $<1$ sebesar 0,55 .

2. Usaha pembesaran ikan nila di Kabupaten Musi Rawas pada pemodal kecil memiliki keunggulan komparatif yang tinggi ditandai dengan nilai DRCR < 1 sebesar 0,37 .

3. Adanya kebijakan pemerintah terhadap input sarana produksi tradable berupa subsidi sangat meberikan manfaat pada petani usaha pembesaran ikan nila di Kabupaten Musi Rawas pada petani pemodal kecil.

4. Hasil analisis sensitifitas pada usaha pembesaran ikan nila di kabupaten Musi Rawas dengan penurunan produksi ikan nila sebesar $10 \%$, penurunan harga ikan sebesar 5,5\% dan peningkatan harga pakan sebesar 7\% maka petani pemodal kecil akan mengalami kerugian. 


\section{Saran}

Adapun saran peneliti dari hasil penelitian:

1. Bagi Pemerintah: Perlu adanya kebijakan input-otput agar dapat melindungi petani usaha pembesaran ikan nila sehingga petani dapat menerima harga privat yang baik dalam meningkatkan penerimaan.

2. Bagi Petani: untuk melakukan peningkatan produksi bagi pemodal kecil dalam usaha pembesaran ikan nila di Kabupaten Musi Rawas karena usaha pembesaran ikan nila memiliki tingkat keunggulan baik secara kompetitif maupun komparatif.

\section{DAFTAR PUSTAKA}

Apridar. 2014. Daya Saing Ekspor Ikan Tuna Indonesia. Penerbit Graha Ilmu. Jakarta.

BPS. 2012. Statistik Eksport Hasil Perikanan Menurut Komoditi Provinsi dan Pelabuhan Asal Ekport. Badan Pusat Statitik. Jakarta.

BPS. 2013. Laporan Produksi Perikanan Budidaya. Badan Pusat Stattistik. Jakarta.

Dinas Peternakan dan Perikanan. 2015. Laporan Tahunan. Pemerintah Kabupaten Musi Rawas.

Ditjen Perikanan Budidaya. 2013. Laporan Produksi Perikanan Budidaya. Direktorat Jenderal Perikanan Budidaya. Jakarta.

Monke, E. A. And E. S. Pearson. 1989. The Policy Analysis Matrix for Agriculture Development. Cornel University Press. London.

Riduan dan Sunarto. 2009. Pengantar Statistika untuk Penelitian Pendidikan, Sosial Ekonomi, Komunikasi dan Bisnis. Penertbit Alfabeta. Bandung. 